\title{
HOW DOES THE REDUCTION OF GLANDULAR TISSUE EFFECT THE FORCE AND BREAST THICKNESS IN MAMMOGRAPHY?
}

\author{
KAKO VPLIVA ZMANJŠANJE ŽLEZNEGA TKIVA NA SILO IN DEBELINO DOJKE PRI \\ MAMOGRAFSKEM SLIKANJU?
}

\begin{abstract}
Manca Pišek, Pia Pšenič Pikelj, Nejc Mekiš, Erna Alukić*
University of Ljubljana, Faculty of Health Sciences, Department of Medical Imaging and Radiotherapy, Zdravstvena pot 5, 1000 Ljubljana, Slovenia
\end{abstract}

*Corresponding author: erna.alukic@zf.uni-lj.si

Received: 8. 11. 2019

Accepted: 29. 4. 2020

https://doi.org/10.47724/MIRTJ.2020.i01.a001

\begin{abstract}
Purpose: To determine whether breast thickness decreases with menopause after the reduction of glandular tissue. We also wanted to know how the decrease in breast thickness affects the compression force and the average glandular dose.

Methods: In this project, we collected data regarding the compression force, breast thickness and mean glandular dose of 300 patients who had mammographic imaging in two views: CC (craniocaudal) and MLO (mediolateral oblique) view. The data were divided into three age groups: 100 patients aged 50 to 55,100 patients aged 60 to 65 and 100 patients aged 70 to 75 years. We used basic statistical tests for measurement purposes, while we used the Shapiro-Wilk test to check normality and the Kruskal-Wallis test to compare the differences.
\end{abstract}

Results and discussion: We presented the results and comparisons in the tables and box plot graphs for CC and MLO views of the left and right breast for compression force, breast thickness and MGD. In the CC view of the both breasts, we found that there were statistically significant differences in thickness between groups 1 and 3, and differences in MGD between groups 1 and 2, and 1 and 3. In the MLO view of both breasts we found that compression force does not increase with the age of patients, which can be attributed to the different size and density of breasts, and different compression force. Higher compression force results in lower MGD and breast thickness.

Conclusion: In the CC view of left and right breast, there is no statistically significant differences in compression force, but thickness and MGD changed between some groups. In the MLO view, only MGD changed. For further research, we recommend taking measurements on a larger sample, and concurrently considering and examining other factors that may affect breast thickness, compression force and MGD.

Keywords: mammographic imaging, compression force, mean glandular dose, breast thickness, glandular tissue

\section{IZVLEČEK}

Namen: Ugotoviti, ali se debelina dojke z leti po menopavzi zmanjšuje glede na zmanjšanje žleznega tkiva pri mamografskem slikanju. Zanimalo nas je tudi, kako zmanjšanje debeline dojke vpliva na kompresijsko silo in povprečno žlezno dozo.

Metode: $\mathrm{V}$ nalogi so bili zajeti podatki o kompresijski sili, debelini dojke in povprečni žlezni dozi 300 pacientk, ki so imele opravljeno mamografsko slikanje v dveh projekcijah, tj. CC (kraniokavdalna) in MLO (mediolateralna poševna) projekcija. Podatke smo razdelili v tri starostne skupine po 100 pacientk: od 50 do 55 (skupina 1), 60 do 65 (skupina 2) in 70 do 75 let (skupina 3). Za izračun smo uporabili osnovne statistične teste; za preverjanje normalnosti vzorca Shapiro-Wilk test, za primerjavo razlik pa Kruskal-Wallis test.

Rezultati in razprava: Pri CC projekciji obeh dojk smo ugotovili, da obstajajo statistično značilne razlike $v$ debelini med 1. in 3. skupino, ter razlike v MGD med skupinama 1 in 2 ter 1 in 3. Pri MLO projekciji obeh dojk so bile razlike statistično značilne pri MGD, in sicer med 1. in 2. ter 1. in 3. skupino. Pri CC in MLO projekciji leve in desne dojke smo ugotovili, da se kompresijska sila ne viša z višjo starostjo pacientk, kar se da pripisati različnim strukturam dojk in različni sili kompresije. Posledično bi se vidneje znižala tudi povprečna žlezna doza in debelina.

Zaključek: Pri primerjavi kompresijske sile pri CC projekciji leve in desne dojke ni statistično značilnih razlik med skupinami, debelina in MGD pa se med nekaterimi starostnimi skupinami razlikujeta. Pri MLO projekciji se spreminja le MGD. Za nadaljnje raziskave $v$ prihodnosti priporočamo zajem meritev na večjem vzorcu ter sočasno upoštevanje in preučitev še ostalih faktorjev, ki lahko vplivajo na debelino dojke, silo kompresije in MGD.

Ključne besede: mamografija, kompresijska sila, povprečna žlezna doza, debelina dojke, žlezno tkivo 


\section{INTRODUCTION}

Mammography is a radiology examination of the breast using $X$-rays. The exam is fast, reliable and accessible (1). It is the most efficient method for (early) breast cancer screening. Tumours with a diameter of only a few millimetres $(\mathrm{mm})$ can be detected. This method has led to a decrease in the breast cancer mortality rate by 20 to $40 \%$ (2). Compression is used in mammography and it is applied using a compression paddle to fix and compress the breast, which facilitates a better signal-to-noise-ratio, the higher homogeneity of the field and thus a high-quality diagnostic mammogram, as well as a lower average glandular dose $(3,4)$.

The breast is essentially composed of fatty, connective and glandular tissue. Over the years, the glandular tissue may undergo atrophy and is transformed into fatty tissue, the connective tissue becomes less firm and the amount of collagen is reduced (5). Glandular, i.e. epithelial tissue is composed of lobules - TDLU (terminal ductal lobular unit), lobuli glandulae mammariae (lobules of mammary gland) and ductuli lactiferi (lactiferous ducts)(6).

A mammogram not only depends on the technical quality of the examination, but also on the tissue content of the examined breast. Younger breasts are composed of more glandular and less fatty tissue, and thus produce an image of dense and relatively homogenous tissue. During and after menopause when fatty tissue is prevalent in breasts, a mammogram is relatively transparent (7). A mammogram image of glandular tissue is radiopaque, whereas fatty tissue is radiolucent, which means that a higher content of fatty tissue results into a more dark and transparent mammogram (6). When preparing for imaging, it is importantfor the radiographer to place the patient in an appropriate position, which can have a significant effect on the quality of a mammogram, dose load and the patient's perception of imaging (8).

Our aim is to determine whether mammography detects a decrease of breast thickness over the years in the postmenopausal period and how the reduced breast thickness affects the compression force and the mean glandular dose (MGD).

\section{METHODS}

A retrospective research method was used, combined with secondary data analysis. The research was conducted between

Table 1: Descriptive statistical properties for compression force for all three age groups of patients

\begin{tabular}{|c|c|c|c|c|c|}
\hline Age group & Average $(\boldsymbol{N})$ & Standard deviation $(\boldsymbol{N})$ & Median $(\boldsymbol{N})$ & Minimum (N) & Maximum (N) \\
\hline From 50 to $5 \mathbf{5}$ & 106.23 & 24.01 & 107.50 & 9.70 & 164.00 \\
\hline From $\mathbf{6 0}$ to $\mathbf{6 5}$ & 108.55 & 24.37 & 106.50 & 53.00 & 158.00 \\
\hline From 70 to 75 & 104.86 & 22.85 & 105.00 & 1.07 & 174.00 \\
\hline
\end{tabular}

Table 2: Descriptive statistical properties for thickness for all three age groups of patients

\begin{tabular}{|c|c|c|c|c|c|}
\hline Age group & Average $(\mathbf{m m})$ & Standard deviation $(\mathbf{m m})$ & Median $(\mathbf{m m})$ & Minimum $(\mathbf{m m})$ & Maximum $(\mathbf{m m})$ \\
\hline From 50 to 55 & 53.69 & 13.04 & 56.00 & 20.00 & 76.00 \\
\hline From 60 to 65 & 51.57 & 12.24 & 53.00 & 24.00 & 79.00 \\
\hline From 70 to 75 & 49.19 & 12.65 & 49.50 & 16.00 & 79.00 \\
\hline
\end{tabular}

Table 3: Descriptive statistical properties for mean glandular dose for all three age groups of patients

\begin{tabular}{|c|c|c|c|c|c|}
\hline Age group & Average (mGy) & Standard deviation (mGy) & Median (mGy) & Minimum (mGy) & Maximum (mGy) \\
\hline From 50 to 55 & 1.40 & 0.55 & 1.31 & 0.66 & 3.90 \\
\hline From 60 to 65 & 1.16 & 0.34 & 1.08 & 0.65 & 2.49 \\
\hline From 70 to 75 & 1.13 & 0.33 & 1.08 & 0.59 & 2.85 \\
\hline
\end{tabular}

Table 4: Statistical analysis of results for the CC view of left breast

\begin{tabular}{|c|c|c|c|c|}
\hline Variable & Pair & Percentage difference & Kruskal-Wallis test & Post hoc analysis \\
\hline \multirow{3}{*}{$\begin{array}{c}\text { Compression } \\
\text { force }\end{array}$} & $1-2$ & $2 \%$ & \multirow{3}{*}{0.460} & \\
\hline & $1-3$ & $-1.3 \%$ & & \\
\hline & $2-3$ & $-3.4 \%$ & & \\
\hline \multirow{3}{*}{ Thickness } & $1-2$ & $-4 \%$ & \multirow{3}{*}{0.043} & 0.653 \\
\hline & $1-3$ & $-8 \%$ & & 0.037 \\
\hline & $2-3$ & $-5 \%$ & & 0.661 \\
\hline \multirow{3}{*}{ MGD } & $1-2$ & $-17 \%$ & \multirow{3}{*}{$<0.001$} & $<0.001$ \\
\hline & $1-3$ & $-19 \%$ & & $<0.001$ \\
\hline & $2-3$ & $-3 \%$ & & 1.000 \\
\hline
\end{tabular}


29 April 2019 and 30 May 2019 in the Ljubljana Community Health Centre (Unit Centre), on a SIEMENS MAMMOMAT INSPIRATION mammogram machine.

We obtained the permission of the head of the Radiology Department in the Ljubljana Community Health Centre, the chief radiographer of the same centre and the Commission of the Republic of Slovenia on Medical Ethics prior to the research. In this study, we collected data regarding patients who had mammographic imaging in two views, i.e. the CC (craniocaudal) and MLO (mediolateral oblique) projection. We collected data regarding the compression force, breast thickness and MGD of 300 patients. They were divided into three age groups: 100 patients aged 50 to 55 (Group 1), 100 patients aged 60 to 65 (Group 2) and 100 patients aged 70 to 75 years (Group 3). All data were captured from anonymised DICOM files and processed using the IBM SPSS STATISTICS program (version 25). We used basic statistical tests for measurement purposes, while we used the Shapiro-Wilk test to check sample normality. The Kruskal-Wallis test and the Dunn Bonferroni post hoc analysis were used to compare the differences in data. The results were shown in form of tables and graphs. A standard statistical level of risk of $5 \%$ was taken into account in verifying hypotheses.

\section{RESULTS}

The measurement results of the CC and MLO views of left and right breasts were presented. The data are broken down according to the compression force, breast thickness and mean glandular dose for each breast separately. The results were compared for each age group.

\section{Craniocaudal view of left breast (CC)}

Tables 1-3 show the basic descriptive statistical properties for compression force, breast thickness during the compression and MGD. Table 4 shows the results of statistical analysis.

\section{Craniocaudal view of right breast (CC)}

Tables 5-7 show the basic descriptive statistical properties for compression force, breast thickness and MGD. Table 8 shows the results of statistical analysis.

Table 5: Descriptive statistical properties for compression force for all three age groups of patients

\begin{tabular}{|c|c|c|c|c|c|}
\hline Age group & Average (N) & Standard deviation (N) & Median (N) & Minimum (N) & Maximum (N) \\
\hline From 50 to 55 & 107.31 & 18.93 & 108.00 & 46.00 & 146.00 \\
\hline From 60 to 65 & 113.18 & 21.09 & 110.00 & 63.00 & 166.00 \\
\hline From 70 to 75 & 108.05 & 19.16 & 105.50 & 55.00 & 180.00 \\
\hline
\end{tabular}

Table 6: Descriptive statistical properties for thickness for all three age groups of patients

\begin{tabular}{|c|c|c|c|c|c|}
\hline Age group & Average $(\mathbf{m m})$ & Standard deviation $(\mathbf{m m})$ & Median $(\mathbf{m m})$ & Minimum $(\mathbf{m m})$ & Maximum $(\mathbf{m m})$ \\
\hline From 50 to 55 & 53.75 & 13.25 & 55.50 & 20.00 & 83.00 \\
\hline From 60 to 65 & 50.94 & 12.42 & 50.00 & 23.00 & 78.00 \\
\hline From 70 to 75 & 49.46 & 11.79 & 51.00 & 17.00 & 77.00 \\
\hline
\end{tabular}

Table 7: Descriptive statistical properties for mean glandular dose for all three age groups of patients

\begin{tabular}{|c|c|c|c|c|c|}
\hline Age group & Average $(\boldsymbol{m G y})$ & Standard deviation (mGy) & Median (mGy) & Minimum (mGy) & Maximum (mGy) \\
\hline From 50 to 55 & 1.42 & 0.56 & 1.35 & 0.70 & 4.01 \\
\hline From 60 to 65 & 1.15 & 0.31 & 1.12 & 0.67 & 1.99 \\
\hline From 70 to 75 & 1.12 & 0.26 & 1.07 & 0.68 & 2.05 \\
\hline
\end{tabular}

Table 8: Statistical analysis of results for the CC view of right breast

\begin{tabular}{|c|c|c|c|c|}
\hline Variable & Pair & Percentage difference & Kruskal-Wallis test & Post hoc analysis \\
\hline \multirow{3}{*}{$\begin{array}{l}\text { Compression } \\
\text { force }\end{array}$} & $1-2$ & $-5 \%$ & \multirow{3}{*}{0.106} & \\
\hline & $1-3$ & $-1 \%$ & & \\
\hline & $2-3$ & $5 \%$ & & \\
\hline \multirow{3}{*}{ Thickness } & $1-2$ & $5 \%$ & \multirow{3}{*}{0.028} & 0.317 \\
\hline & $1-3$ & $8 \%$ & & 0.024 \\
\hline & $2-3$ & $3 \%$ & & 0.910 \\
\hline \multirow{3}{*}{ MGD } & $1-2$ & $19 \%$ & \multirow{3}{*}{$<0.001$} & $<0.001$ \\
\hline & $1-3$ & $21 \%$ & & $<0.001$ \\
\hline & $2-3$ & $3 \%$ & & 1.000 \\
\hline
\end{tabular}




\section{Mediolateral oblique view of left breast (MLO L)}

Tables 9-11 show the basic descriptive statistical properties for compression force, breast thickness and MGD. Table 12 shows the results of statistical analysis.

\section{Mediolateral oblique view of right breast (MLO R)}

Tables 13-15 show the basic descriptive statistical properties for compression force, breast thickness and MGD. Table 16 shows the results of statistical analysis.

\section{DISCUSSION}

ACC projection of the left breast showed that the compression force does not increase with respect to our three age groups. By increasing the force, the thickness of the compressed breast reduces, which means that the mean glandular dose should decrease. In our case, the thickness differs in the first and the third group, where the thickness of the breast in the first group is highest and lowest in the third group. Waade et al. (4) determined that at some level a higher compression force no longer leads to a lower breast thickness; it only causes a more painful and unpleasant examination for the patient. Our study established that the MGD of the first group is higher than the MGD of the second and third group, while there are no differences in MGD between the second and third group. Compared to other tissues, glandular breast tissue is most sensitive to ionising radiation. Therefore, the highest mean glandular dose is expected in the first group and the lowest in the third group. A Sydney study compared the differences in compression force in cases when patients alone compress the breast and on the other hand when radiographers perform the compression. It was determined that the compression force is many times lower when the compression is done by radiographers. Consequently, the breast thickness differed by up to $11 \mathrm{~mm}$ (9). According to a six-year study by Mercer et al., $(10,11)$ the applied force also depends on the radiographer who performs the examination. When a patient was imaged by different radiographers, statistically significant differences occurred. It is likely that a higher compression force on the breast could have been applied more often in our study, without causing discomfort or pain to the patient. However, it would to some

Table 9: Descriptive statistical properties for compression force for all three age groups of patients

\begin{tabular}{|c|c|c|c|c|c|}
\hline Age group & Average (N) & Standard deviation (N) & Median $(N)$ & Minimum (N) & Maximum (N) \\
\hline From 50 to 55 & 126.14 & 30.88 & 122.50 & 32.00 & 188.00 \\
\hline From 60 to 65 & 129.94 & 32.06 & 132.00 & 1.30 & 187.00 \\
\hline From 70 to 75 & 125.04 & 29.99 & 122.50 & 1.30 & 191.00 \\
\hline
\end{tabular}

Table 10: Descriptive statistical properties for thickness for all three age groups of patients

\begin{tabular}{|c|c|c|c|c|c|}
\hline Age group & Average $(\mathbf{m m})$ & Standard deviation $(\mathbf{m m})$ & Median $(\mathbf{m m})$ & Minimum $(\mathbf{m m})$ & Maximum $(\mathbf{m m})$ \\
\hline From 50 to 55 & 54.61 & 14.33 & 57.50 & 22.00 & 81.00 \\
\hline From 60 to 65 & 52.69 & 14.62 & 54.00 & 24.00 & 82.00 \\
\hline From 70 to 75 & 52.97 & 14.02 & 54.50 & 16.00 & 84.00 \\
\hline
\end{tabular}

Table 11: Descriptive statistical properties for mean glandular dose for all three age groups of patients

\begin{tabular}{|c|c|c|c|c|c|}
\hline Age group & Average (mGy) & Standard deviation (mGy) & Median (mGy) & Minimum (mGy) & Maximum (mGy) \\
\hline From 50 to 55 & 1.45 & 0.56 & 1.35 & 0.67 & 3.64 \\
\hline From 60 to 65 & 1.23 & 0.38 & 1.16 & 0.64 & 2.22 \\
\hline From 70 to 75 & 1.25 & 0.37 & 1.18 & 0.68 & 3.21 \\
\hline
\end{tabular}

Table 12: Statistical analysis of results for the MLO view of left breast

\begin{tabular}{|c|c|c|c|c|}
\hline Variable & Pair & Percentage difference & Kruskal-Wallis test & Post hoc analysis \\
\hline \multirow{3}{*}{$\begin{array}{c}\text { Compression } \\
\text { force }\end{array}$} & $1-2$ & $-3 \%$ & \multirow{3}{*}{0.270} & \\
\hline & $1-3$ & $1 \%$ & & \\
\hline & $2-3$ & $4 \%$ & & \\
\hline \multirow{3}{*}{ Thickness } & $1-2$ & $4 \%$ & \multirow{3}{*}{0.331} & \\
\hline & $1-3$ & $3 \%$ & & \\
\hline & $2-3$ & $-1 \%$ & & \\
\hline \multirow{3}{*}{ MGD } & $1-2$ & $15 \%$ & \multirow{3}{*}{0.002} & 0.004 \\
\hline & $1-3$ & $14 \%$ & & 0.016 \\
\hline & $2-3$ & $-2 \%$ & & 1.000 \\
\hline
\end{tabular}


extent cause a reduction in breast thickness as well as in mean glandular dose. Poulos and McLean (9) discovered a connection between the size of a breast and the force that can be applied. Larger breasts allow for a higher force. Since numerous data were obtained from anonymous DICOM files, it is not clear whether older women had larger breasts, which could be one of the reasons for a non-decreasing compression force in age groups.

According to Hoflehner et al., (12) there are two categories of breasts: firm and soft. The thickness of soft breasts after the applied force of $80 \mathrm{~N}$ accounts for $40 \mathrm{~mm}$, while it is higher for firm breasts. For each subsequent $30 \mathrm{~N}$, the thickness changes by 1 to $4 \mathrm{~mm}$. The thickness of soft breasts under similar conditions changes by more than $4 \mathrm{~mm}$ (9). In our research, the patients were divided into age groups. However, the category (firm or soft breasts) was not determined for patients from individual age groups.

There were no differences in the compression force nor in the thickness of the compressed breast in the mediolateral oblique projection for any of the age groups, but there were statistical differences in mean glandular dose between the first and the second group, and the first and the third group. The dose and quantity of glandular tissue were lower.
Menstrual function and thus reproductive abilities of women cease in menopause, which is connected to undesired changes in body weight and its composition. Generally, the body weight increases and results in higher body fat (13). If we assume that the women in our study also gained weight and breast density during the menopausal period, our results are fairly expected. The larger and denser the breast is, the higher the thickness and consequently the mean glandular dose will be. The difference in breast density for women from the first, second and third groups is therefore smaller or non-existent. Thus, the differences between data for the three age groups are smaller.

\section{CONCLUSION}

According to literature, it was expected that a higher age group and thus a greater atrophy of glandular tissue would result in an increasing compression force on the breast, a decreasing tissue thickness as well as a mean glandular dose. We determined that there are no statistically significant differences in the CC view of left and right breasts. The only exceptions were thickness, which only decreases between the first and third age group, and MGD, which decreases between

Table 13: Descriptive statistical properties for compression force for all three age groups of patients

\begin{tabular}{|c|c|c|c|c|c|}
\hline Age group & Average (N) & Standard deviation (N) & Median (N) & Minimum (N) & Maximum (N) \\
\hline From 50 to 55 & 122.34 & 34.13 & 125.00 & 1.01 & 186.00 \\
\hline From 60 to 65 & 124.68 & 23.99 & 122.50 & 65.00 & 182.00 \\
\hline From 70 to 75 & 127.40 & 34.40 & 123.00 & 1.06 & 190.00 \\
\hline
\end{tabular}

Table 14: Descriptive statistical properties for thickness for all three age groups of patients

\begin{tabular}{|c|c|c|c|c|c|}
\hline Age group & Average $(\mathbf{m m})$ & Standard deviation $(\mathbf{m m})$ & Median $(\mathbf{m m})$ & Minimum $(\mathbf{m m})$ & Maximum $(\mathbf{m m})$ \\
\hline From 50 to 55 & 54.28 & 13.94 & 57.00 & 18.00 & 78.00 \\
\hline From 60 to 65 & 51.45 & 13.78 & 53.00 & 22.00 & 86.00 \\
\hline From 70 to 75 & 52.71 & 14.09 & 54.00 & 18.00 & 82.00 \\
\hline
\end{tabular}

Table 15: Descriptive statistical properties for mean glandular dose for all three age groups of patients

\begin{tabular}{|c|c|c|c|c|c|}
\hline Age group & Average (mGy) & Standard deviation (mGy) & Median (mGy) & Minimum (mGy) & Maximum (mGy) \\
\hline From 50 to 55 & 1.45 & 0.58 & 1.32 & 0.71 & 3.86 \\
\hline From 60 to 65 & 1.22 & 0.37 & 1.14 & 0.66 & 2.76 \\
\hline From 70 to 75 & 1.24 & 0.33 & 1.18 & 0.70 & 2.54 \\
\hline
\end{tabular}

Table 16: Statistical analysis of results for the MLO view of right breast

\begin{tabular}{|c|c|c|c|c|}
\hline Variable & Pair & Percentage difference & Kruskal-Wallis test & Post hoc analysis \\
\hline \multirow{3}{*}{$\begin{array}{c}\text { Compression } \\
\text { force }\end{array}$} & $1-2$ & $-2 \%$ & \multirow{3}{*}{0.642} & \\
\hline & $1-3$ & $-4 \%$ & & \\
\hline & $2-3$ & $-2 \%$ & & \\
\hline \multirow{3}{*}{ Thickness } & $1-2$ & $5 \%$ & \multirow{3}{*}{0.246} & \\
\hline & $1-3$ & $3 \%$ & & \\
\hline & $2-3$ & $-2 \%$ & & \\
\hline \multirow{3}{*}{ MGD } & $1-2$ & $16 \%$ & \multirow{3}{*}{0.001} & 0.002 \\
\hline & $1-3$ & $14 \%$ & & 0.017 \\
\hline & $2-3$ & $-2 \%$ & & 1.000 \\
\hline
\end{tabular}


the first and second group and between the first and third group. In the MLO view of left and right breasts, only the MGD changes between the first and the second group, and the first and the third group, while the other two parameters remain the same. Our research did not prove that the breast thickness decreases over time in the postmenopausal period and therefore does not affect the compression force and dose load for the patient, as expected. Since the results failed to meet our expectations, it would be recommended in further studies to increase the sample and also take other factors into account. By reviewing literature, we came across the following factors: breast size, categorisation into soft and firm breasts, appropriately applied compression force, review of mammograms. It would also be advisable to conduct research in another field of mammographic diagnostics.

\section{References}

1. Dumky H, Leifland K, Fridell K. The Art of Mammography With Respect to Positioning and Compression-A Swedish Perspective. Journal of Radiology Nursing. 2018 Mar;37(1):41-8.

2. Katzen J, Dodelzon K. A review of computer aided detection in mammography. Clinical Imaging. 2018.

3. Branderhorst W, de Groot JE, Highnam R, Chan A, Böhm-Vélez $M$, Broeders MJM, et al. Mammographic compression--a need for mechanical standardization. European journal of radiology. 2015;

4. Waade GG, Sanderud A, Hofvind S. Compression force and radiation dose in the Norwegian Breast Cancer Screening Program. European Journal of Radiology. 2017;88:41-6.

5. Ellis $\mathrm{H}$, Mahadevan V. Anatomy and physiology of the breast. Surgery (Oxford). 2013 Jan;31(1):11-4.
6. Mušič $M M$, Hertl $K$, Kadivec $M$, Podkrajšek $M$, Jereb $S$. Rentgenska in ultrazvočna anatomija dojke. Radiology and Oncology. 2004;38(SUPPL. 1):51-7.

7. Jančar B. Mamografija: metoda za zgodnje odkrivanje raka dojk. Društvo onkoloških bolnikov Slovenije. 2004.

8. Balleyguier C, Cousin M, Dunant A, Attard M, Delaloge $S$, Arfi-Rouche J. Patient-assisted compression helps for image quality reduction dose and improves patient experience in mammography. European Journal of Cancer. 2018;103:137-42.

9. Poulos A, McLean D.The application of breast compression in mammography: A new perspective. Radiography. 2004;10(2):131-7.

10. Mercer CE, Hogg P, Szczepura K, Denton ERE. Practitioner compression force variation in mammography: A 6-year study. Radiography. 2013;

11. Mercer CE, Hogg P, Lawson R, Diffey J, Denton ERE. Practitioner compression force variability in mammography: a preliminary study. The British Journal of Radiology. 2013 Feb;86(1022):20110596.

12. Hoflehner H, Pierer G, Rehak P. "'Mammacompliance'”: an objective technique for measuring capsular fibrosis. Plastic and reconstructive surgery. 1993 Nov;92(6):107884.

13. Kirchengast $S$, Gruber D, Sator M, Huber J. Postmenopausal weight status, body composition and body fat distribution in relation to parameters of menstrual and reproductive history. Maturitas. 1999. 